Article

\title{
Revisiting the Use of the Proximity Lexicon in the Classroom for Immigrant Populations at Risk of Social Exclusion: Does It Really Help?
}

\author{
Antonio-Manuel Ávila-Muñoz \\ General Linguistics, Universidad de Málaga, 29071 Málaga, Spain; amavila@uma.es
}

Received: 22 April 2019; Accepted: 17 June 2019; Published: 19 June 2019

check for updates

\begin{abstract}
This paper shows the convenience of using linguistic resources in foreign language teaching based on the proximity lexicon (dialectal and local) in order to facilitate the integration of socially vulnerable immigrant groups. The social barriers facing them intensify because of lack of knowledge of the linguistic varieties of the host countries and their functions. This study is a continuation of another one published in 2019 in which we presented a theoretical model of language teaching based on the gradual introduction of specific lexical material with the aim of facilitating sociocultural adaptation. The proximity lexicon associated to communal belonging meanings was considered a powerful social inclusion tool. We worked with two student samples to confirm the efficacy of the model. In a group, the dialectal strategy was employed in a programmed and conscious manner, whereas in the other one, the control group, the model was not followed. The results are based on the answers to questions in a wellbeing questionnaire designed ad hoc to evaluate the efficacy of the proposal. The group to which the proposed system was applied showed a greater degree of social wellbeing, satisfaction and adaptation.
\end{abstract}

Keywords: Proximity lexicon; teaching; immigrants; social vulnerability; (non) adaptation

\section{Introduction}

Population movements have been a constant throughout the history of mankind. Nevertheless, from the end of the XIX century, migratory flows have intensified and brought sociolinguistic, and unexpected, consequences which merit discussion and solution in case of emerging conflicts (Moreno-Fernández 2009; Fernández-Vítores 2013; Piller 2016; EUROSTAT 2017). In this paper, we present the early results of the application of a linguistic performance model, which aims, from the perspective of social dialectology, at facilitating the sociocultural integration of the more vulnerable immigrant groups by way of the teaching of the proximity lexicon (dialectal and local) in the Spanish as a foreign language (SFL) classroom. The epistemological foundation of this model was presented in Ávila-Muñoz (Forthcoming), although in that previous work, its practical efficacy was still to be demonstrated. The first section of this paper is dedicated to the synthesis of the more relevant theoretical fundamentals of the model and in the second one, the results of its application in the SFL classroom are submitted. This application took place in an NGO located in the city of Malaga working with migrants under risk of social exclusion. The results are based on the use and interpretation of wellbeing tests applied to a sample of students after their having completed their Spanish course. To insure the reliability of our proposal, we worked with two groups of informants to the first of which the proposed model was applied by way of showing the Proximity lexicon systematically and consciously, aiming at its transformation into a social integration tool. The second one-the control group-was not given language teaching based on the model. 


\section{The Linguistic Model of Social Integration Based on the Teaching of the Proximity Lexicon}

\subsection{Principles}

As shown in Ávila-Muñoz (Forthcoming), the proposed model is based on the following principles:

1. Principle of Group Belonging. Languages have units which function as solidarity links among members of speech communities because they connote sharing of cultural habits. These units are especially significative at the semantic-lexical level because of two well-documented motives in cognitive sociolinguistics (Moreno-Fernández 2013a). The first one being that each lexical variant carries associated underlying social meanings; in the case of localisms, this motive is linked to the history of the immediate sociocultural context. The second motive is that sociolinguistic conscience particularly sensible to these units, interprets them as symbols of social identity (Sheppard 2015; Regan et al. 2016; Dempster and Hargrave 2017; Stokes 2017).

2. The Integration Principle. If these units are identified systematically and consciously, without prejudices, in foreign language teaching to immigrants, or even in general language classes to migrants who speak the language of the host community, we would be providing a sociocultural integration tool. This tool might also modify attitudes of negation or rejection by members of the host community (Ariolfo 2012; CIS 2015; Dempster and Hargrave 2017; Wheeler 2019).

3. Principle of the usefulness of an entertaining multidimensional approach. The work with the specific vocabulary of the nearest social context assumes an additional motivation for both the teacher and the student. On the one hand, the teacher may know, respect and foster the use of this lexicon among his students. On the other hand, the characteristics of this lexicon lend support to the realisation of complementary workshops with the aim of backing the explanation of the connoted value of these linguistic units.

This approach can be applied to any foreign language teaching to migrants, but it acquires its whole dimension with those students who wish to remain and settle - either transiently or indefinitely-in a region of the host country. In addition to being an interesting approach to any situation involving the teaching of foreign languages or varieties of a language, we believe that these principles can lead to a pedagogical strategy of far-reaching sociocultural integration of vulnerable groups.

The proximity lexicon (dialectal and local) not registered in general dictionaries or marked as specific of concrete places, can be observed as complete forms (for example, in Andalusia, borrachuelo, 'fried dough eaten during the Christmas/Easter seasons') or as particular meanings of general forms (in Malaga, pitufo 'small bread roll'). The proposal goes beyond the classroom and becomes a space for debate that would help to diminish the negative effects of the social marginalisation to which the more unprotected migrants are subjected (Moreno-Fernández 2013b; Sancho-Pascual 2013; Johnson and Berry 2014; Bravo-García et al. 2014). Our ultimate objective is therefore, the creation of a theoretical model of language teaching that on the bases of description, explanation and understanding of the sociolinguistic situation caused by these population flows, becomes an integration tool, above all for the groups more likely to suffer social exclusion. It is a question of facilitating the access to the knowledge of the language and the connoted usages associated to the employment of some elements typical of the linguistic variety nearest to the area where the learning process takes place.

One of the main advantages of this model is the creation of a discussion space among the agents involved in the language teaching process to migrant populations. From the practical problems facing teachers, we aim at making our proposal the beginning of a debate on the need to create teaching models based on tools whose function will be to show the linguistic variety to its full extent with the objective of facilitating social integration (Mallows 2014; Egli and Höchle 2016; Devereaux and Palmer 2019). 


\subsection{Theoretical Approaches and Operational Areas}

The objective is the creation of a programming strategy which allows the incorporation of new resources to those normally used in language teaching. In order to achieve it, our model proposes procedures compatible with the elaboration of didactic programmings, which may even be in use. In sum, what is needed is the generation of a proposal with a verifiable efficacy easily put into practice by teachers, permitting both linguistic learning and the necessary social integration of the students.

Our proposal presupposes the convenience of using the Proximity lexicon in the language classroom, be it mother or foreign tongue, as a strategy for the social integration of migrants. However, this lexicon should be a reduced part of the whole lexicon; its verified social cohesion function, with the active connotations in the competence of the speakers of the local groups (Ávila-Muñoz 2017), makes its inclusion recommendable in the lexical selection models employed in the language teaching for vulnerable groups.

Our theoretical model with the inclusion of the Proximity lexicon in the language teaching classroom may be organised as a structure of concentrical crowns, built in five stages:

1. Adequate selection of the lexicon. The common basis is formed by the general lexicon of very frequent use, not dependent on the communicative situation (Frequency Lexicon: Davies 2005; Lonsdale and Bras 2009) and availability, habitually associated to concrete situations (Lexical Availability Ávila-Muñoz and Ponsoda 2010; Bombarelli 2005). From this common structure, our proposal assumes the introduction of some proximity elements, taking advantage of the linkage of contents of didactic units as presented in the system of concentrical crowns in Figure 1.

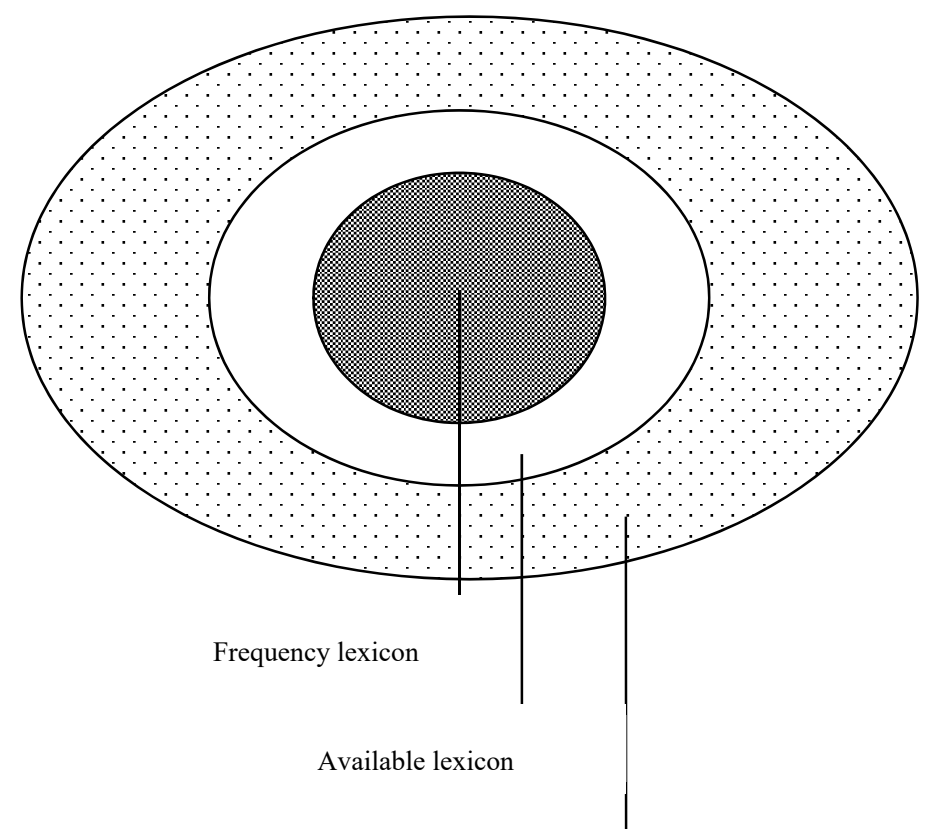

Proximity lexicon

Figure 1. Representation of the general lexical selection model based on the concentrical crowns. (Ávila-Muñoz 2017).

The always active nucleus present in the Frequency Lexicon is generally formed by grammatical words or those of scarcely precise semantic content: conjunctions, articles, prepositions and some nouns or verbs of polyvalent or ambiguous character (Ávila-Muñoz 1999). This nucleus is complemented as a function of the concrete communicative situation and of the words associated to it. Lexical availability refers to habitual vocabulary in concrete thematic contexts, for instance: family, human body, weather, and politics. The structure of the proximity lexicon can be observed as well as a wave system generated 
round a nucleus formed by this type of lexicon employed more often in the speech community. These waves distance themselves from the centre as the frequency of its terms diminishes as shown in Figure 2, which refers to the use of a series of localisms in the city of Malaga (Ávila-Muñoz 2017) whose gloss appears in Table 1.

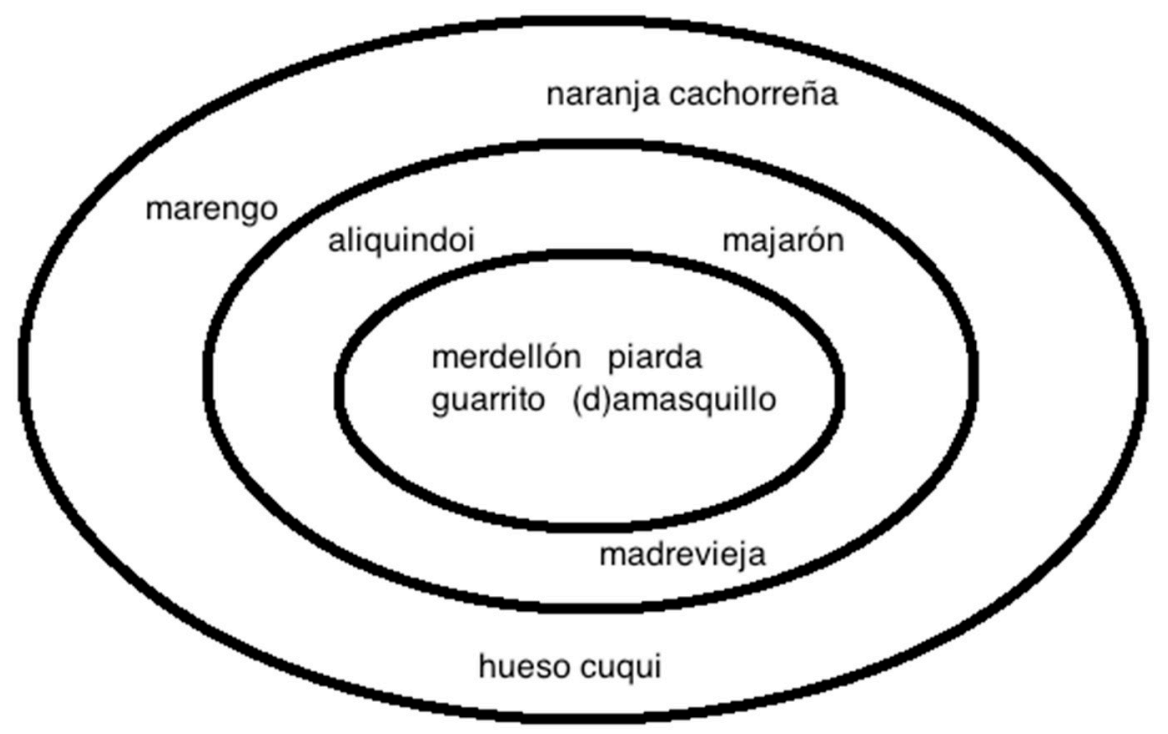

Figure 2. Representation of a sample of the local lexicon of Malaga based on concentrical waves according to frequency of use (Ávila-Muñoz 2017).

Table 1. Gloss of the localisms in Figure 2.

\begin{tabular}{ll}
\hline \multicolumn{1}{c}{ Localisms } & \multicolumn{1}{c}{ Gloss } \\
\hline merdellón & 'not very fine, pretentions, vulgar' \\
piarda & 'play truant' (UK), 'play hookey / hooky'(USA) \\
guarrito & 'drill' \\
(d)amasquillo & 'apricot' \\
madrevieja & 'sewer' \\
aliquindoi & 'to be alert' \\
majarón & 'crazy, fool' \\
hueso cuqui & 'bone of the rump' \\
marengo & 'fish peddler' \\
naranja & 'bitter orange' \\
cachorreña & \\
\hline
\end{tabular}

From the model of general lexical representation suggested in Figure 1, the teacher should select the more appropriate words for each moment and social context in order to guarantee his students' learning and make their sociocultural integration easier according to each type of education:

a. On the one hand, in the case of the teaching of foreign languages, our proposal could be applied to those units related to all areas of communicative relevance proposed by the European Council in the European Common Frame of Reference for Languages (European Council 2002) or the oral linguistic recruitment guides presented by the American Council on the Teaching of Foreign Languages (ACTFL 2012).

b. On the other hand, the Spanish non-university educational system could adapt, with certain ease, our proposal to the subject of Lengua Española (or the corresponding co-official one in those autonomous communities in which it exists) in order to work with students, both in the primary and secondary levels, especially in the latter. 
Given the specificity of the proximity lexicon, an optimal selection of the communication domains or didactic units should be made, in which the proposal could be applied according to the most evident presence of this type of lexical items. For example, in the case of foreign language teaching, our experiment was done with the didactic unit related to the MCER proposal 'Food and drink'. Together with general elements such as agua 'water', refresco 'soft drink', or limonada 'lemonade', we included others more specific to the area, which are shown in Table 2. In our case, these words come from a previous study in which as mentioned before, the proximity lexicon had a clear importance as a local identifier factor (Ávila-Muñoz 2017).

Table 2. Proximity lexicon employed in the experiment (Ávila-Muñoz 2017).

\begin{tabular}{ll}
\hline \multicolumn{1}{c}{ Word } & \multicolumn{1}{c}{ Gloss } \\
\hline $\begin{array}{l}\text { agu< }<(j)>\text { apala }<(d)>a \\
\text { arenca }\end{array}$ & 'sword fish' \\
vitoriano & 'herring' \\
borrachuelo & 'small-sized anchovy' \\
$<(d)>$ amasquillo & 'Christmas / Easter sponge cakes covered with rum' \\
pitufo & 'apricot' \\
cachorreña & 'small piece of bread' \\
sombra & 'bitter orange' \\
nube & 'white coffee' coffee with some milk (+ coffee - milk $)$ \\
\hline
\end{tabular}

2. The selection of the proximity lexicon should be adjusted to the model of concentrical crowns shown in Figure 2. The more frequent form-known and used by a great part of speakers of the local speech community-would be included in the centre and as they distance themselves from the initial nucleus, other forms of a lesser frequency of use would appear. For the design of the "Food and drink" didactic unit employed in our experiment, the model was fixed as shown in Figure 3.

The words included in the central circles or "crowns" of Figure 3, thus being more frequent and representative of the active Malaga proximity lexicon (nube, sombra, pitufo, borrachuelo, <d >amasquillo, vitoriano, arenca) should become the first lexical social integration tools and could be used for the intermediate levels proposed by ECFR (A2-B1) or the descriptors of ACTFL (Lower Intermediate, Intermediate). The more peripheral agujapala $<(d)>a$ and cachorreña forms in Figure 3 , are local meanings recognised by members of the Malaga speech community, but little or not used (passive lexicon), so that they could be assigned to higher levels although they were used in our experiment given the willing welcome by our students to the activity. In case the organisation of the thematic nuclei into expansion lexical waves should not be possible, the teacher could work with the more general model shown in Figure 2 and teach more widely used proximity elements without having to adjust obligatorily to a concrete didactic unit.

3. After an adequate vocabulary selection, activities may be proposed concerning cultural information exchange about habits related to the themes used for the introduction of the lexicon. In our experiment, activities were organised in which the students' gastronomic experiences and traditions were shared.

4. These practical activities with the students should be backed by seminars, informal discussions or debates, and diverse activities outside the classrooms or teaching environments were encouraged. In our case, participation in gastronomic fairs or cooking workshops were organised, where the students were allowed to apply in a practical way what had been presented theoretically.

5. Finally, it is necessary to share and put into practice the knowledge thus acquired so as to evaluate the real efficacy of the Proximity lexicon as a tool towards sociocultural integration. 


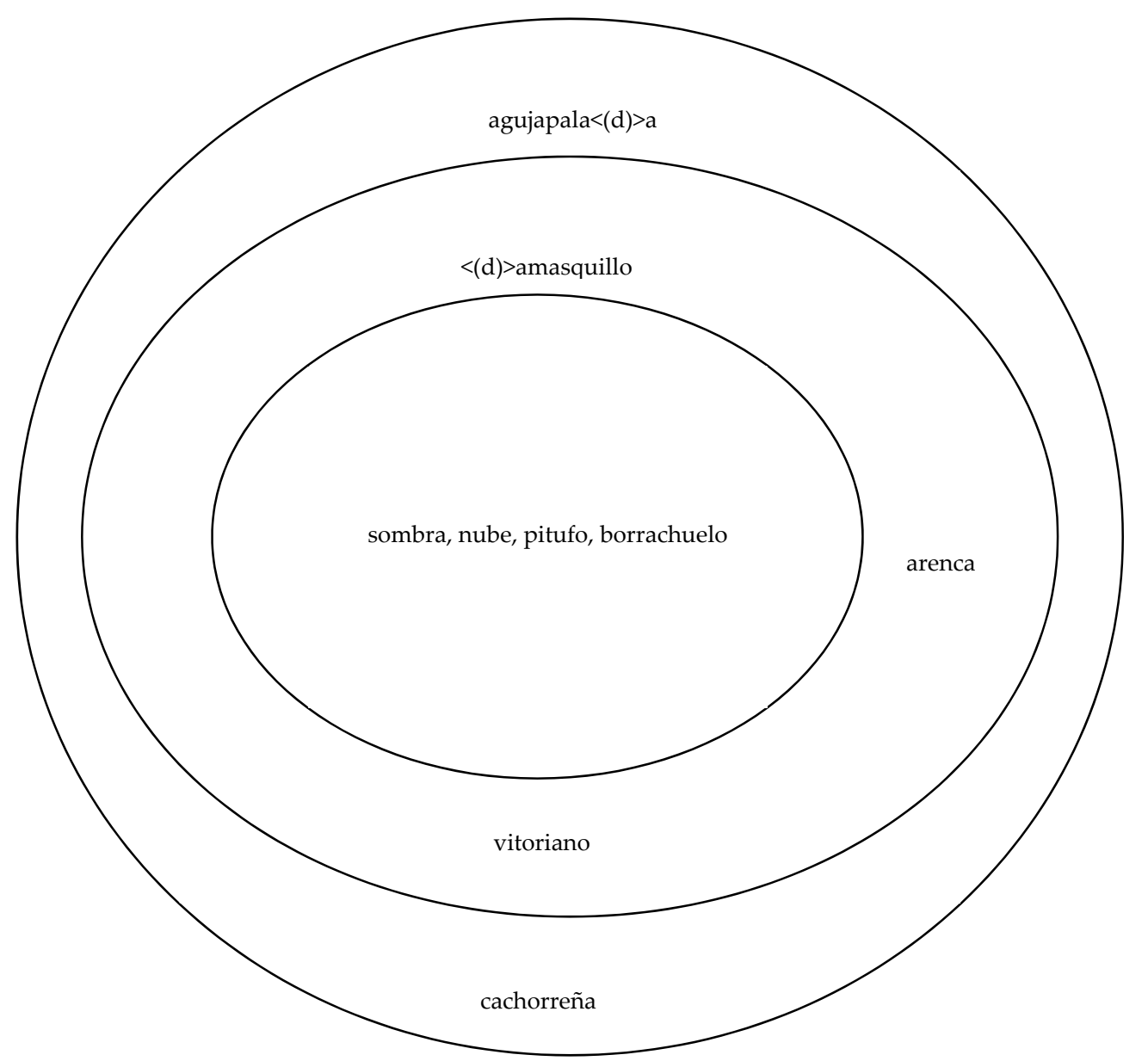

Figure 3. Model of crowns for the lexical proximity selection based on frequency of use (Food and drink) (Ávila-Muñoz 2017).

\section{Hypothesis and Design of Variables}

With the object of verifying the efficacy of our proposal, during 2018 we contacted several NGOs working with migrant groups under risk of social exclusion in the city of Malaga. We came to the conclusion that Málaga Acoge (Malaga Welcomes You) was the one that fulfilled all the requirements to implement our model:

1. It had active courses of Spanish as a foreign language.

2. The students were classified into groups according to their level of knowledge of the Spanish language. The criteria and proposals of ECFR were employed in the evaluation of their idiomatic command of the language.

3. Every level had a sufficient number of students.

4. Additionally, there was more than one group for each different level of knowledge of the language.

In a first approximation, we believed it convenient to work with Spanish B1 level students as the course had already started at the beginning of our research. We did not have more than a quarter of them to carry out our experiment and it seemed convenient to put our model into practice at that intermediate level. It was also important to keep a control group which during their learning process, did not receive any stimulus by way of the Proximity lexicon and if it did, the stimulus was not to be given in the systematic and controlled manner required by our research.

Both groups constitute the independent variable of our work and from its design, we were able to build the main hypotheses of the present research: 
1. Hypothesis of personal satisfaction. After the implementation of the didactic model which supports this work, there will be a statistically superior and significative difference in the experimental group in contrast with the control group in its perception of local integration, wellbeing and personal satisfaction.

2. Hypothesis of integration. Likewise, it is to be expected that the positive perception of vital wellbeing among the individuals which form the experimental group may lead them to formulate plans of possible plans of a future and integration in the host community to a greater degree than the members of the control group.

With the objective of confirming both hypotheses, we carried out an analysis of correlations between dependent and independent variables with the results which are presented in the following chapter. The dependent variables were built on the bases of the answers given by the informants to the items included in the sociological questionnaire of wellbeing (Appendix A). The results were correlated with the independent variable (group to which the individual belonged: experimental group, Group A; control group, Group B). The idea was to establish a cause-effect relation between the variables under study so that the belonging to each group should justify the level of satisfaction as formulated initially in the hypotheses.

We had a total sample of 40 students. Half of them $(N=20)$ were offered the learning system which contained the "Food and drink" unit. We chose this unit because of its traditional use in foreign language teaching. In addition, a previous study gave us enough local terms connected with this unit. As we will mention later, it is important a previous study of specific situations to use the proposal model in other didactic units. At the same time, as mentioned, a control group of 20 students was kept to which the model was not applied (Group B), even though the rest of educational process was identical (same learning system, same didactic unit Food and drink). The main difference was the systematic way that the experimental group learnt local lexicon. As obvious, the teachers in the control group could use this lexical forms eventually. The difference was the systematic and conscious way that defines the experimental group.

Throughout the last quarter of the course (from March to June 2018), the teachers under contract to the NGO, were asked to apply the proximity-based model to the members of Group A. Naturally, the teachers were previously informed of the nature of the activity and the lexicon model methodology better suited to be implemented with Group A. Furthermore, a group of students who had been previously informed and trained, volunteered as auxiliary instructors during that quarter. The auxiliary group helped to organise workshops and activities related to the selected didactic unit: local cooking workshops, excursions to gastronomic provincial fairs and an end-of-course celebration, where local food and drinks were exchanged. The exchange also included food and drinks from the migrants' homelands. As mentioned before, the lexical items employed came from the previous study and selection (Ávila-Muñoz 2017) and were shown in Table 2.

At the end of the course, the students were asked to fill the wellbeing questionnaire shown as Appendix A. In the following section comments are given on the more significative results from the analysis of those questionnaires, that were created ad hoc to improve the actual research from previous studies (Diener et al. 1985; Atienza et al. 2000; Pons et al. 2002)

\section{Sample}

All subjects gave their informed consent for inclusion before they participated in the study. The study was conducted in accordance with the Declaration of Helsinki, and the protocol was approved by the Ethics Committee of ECOPASOS (FFI2015-68171-C5-1-P).

The main social and personal characteristics of our informants are synthesised in Tables $3-5$ and provide the description of our sample. 
Table 3. Characteristics of the sample. Gender and origin.

\begin{tabular}{cccccccc}
\hline & & \multicolumn{2}{c}{ Gender } & & Origin & \multirow{2}{*}{ Total } \\
\cline { 3 - 7 } & Male & Female & Europe & Africa & Asia & \\
\hline \multirow{2}{*}{ Group A } & 12 & 8 & 1 & 16 & 3 & 20 \\
\hline Total & Group B & 12 & 8 & 0 & 18 & 2 & 20 \\
\hline
\end{tabular}

Table 4. Characteristics of the sample. Completed studies.

\begin{tabular}{lccccccc}
\hline & \multicolumn{5}{c}{ Studies That Were Completed } & Total \\
\cline { 3 - 7 } & $\begin{array}{l}\text { No School } \\
\text { Attendance } \\
\text { Whatsoever }\end{array}$ & $\begin{array}{c}\text { No, but (s)he } \\
\text { Attended School }\end{array}$ & Primary & Secondary & Professional \\
& Group A & 4 & 1 & 14 & 1 & 0 & 20 \\
& Group B & 8 & 4 & 7 & 0 & 1 & 20 \\
\hline Total & 12 & 5 & 21 & 1 & 1 & 40 \\
\hline
\end{tabular}

Table 5. Recodified educational level. Distribution by groups.

\begin{tabular}{lcccc}
\hline & & \multicolumn{2}{c}{ Recodified Education } & \multirow{2}{*}{ Total } \\
\cline { 3 - 4 } & Gevel 0 & Level 1 & \\
\hline & Group A & 5 & 15 & 20 \\
& Group B & 12 & 8 & 20 \\
\hline Total & & 17 & 23 & 40 \\
\hline
\end{tabular}

Most of the migrants came from Africa, although in both groups there were people from Asia and only one was from a European country in Group A (Table 3). The number of males was somewhat higher than that of females, but the imbalance was identical in both groups $(M=12, F=8)$.

A recodified version more adjusted to the informants' educational reality was done based on the data in Table 4. Thus, the values were reorganised into two variants according to the degree of completion of some educational stages (Level 1, $N=23$ ) or not (Level $0, N=17$ ). We believe that the reorganisation shown in Table 5 is a better representation of our informants' situation than that of Table 4 and it is more adjusted to the prevalent academic situation in the western world.

Most of the individuals in Group A fit in Level $1(\mathrm{~N}=15)$, the opposite situation occurring in Group B, since almost all its members belong to educational level 0. Table 6 shows that most males indicated that their study rank corresponded to Level 1 in our recodification $(\mathrm{N}=18)$, while most females belonged to Level $0(\mathrm{~N}=11)$.

Table 6. Educational level according to gender.

\begin{tabular}{ccccc}
\hline \multirow{2}{*}{ Gender } & \multicolumn{2}{c}{ Recodified Education } & \multirow{2}{*}{ Total } \\
\cline { 2 - 4 } & Level 0 & Level 1 & \\
\hline M & 6 & 18 & 24 \\
& F & 11 & 5 & 16 \\
\hline Total & 17 & 23 & 40 \\
\hline
\end{tabular}

Most of the members of the sample had arrived to Malaga between a year and less than a year (Group A = 17; Group B = 15) and only one had been more than five years in the city. The rest had been between 1 and 5 years in Malaga (Group A = 3; Group B =4). Almost all had had very frequent 
contact with their country (between two or more times every week and every day). Only 2 informants from Group A indicated that they kept very sporadic contact with their country (more than twice monthly). Half of the sample did not answer the questions related to the work they had (Group A = 11; Group B =9), which made us think they were unemployed or in an illegal situation at the time of the interview. It is relevant to point out that of those who answered those questions, almost all expressed that they were very little/little satisfied with their work and only one person of Group B stated that (s)he was very satisfied with her or his employment situation. Additionally, it was lamentable that 30 of our informants had suffered some racist or xenophobic incidents since the time they arrived in Spain (Group A = 16; Group B =14), whereas 4 classified such incidents as grave and 26 as Not grave.

Most of the informants indicated that they shared their free time only with people of the same origin or culture (Group A = 13; Group B = 17). However, 6 people from Group A and only 1 from Group B also socialised with Spaniards. Almost none of the migrants belonged to associations or social groups (Group A = 18; Group B $=18$ ) and only 4 participated in associations, which were anyway formed by people of their own origin or culture (Group A = 2; Group B = 2).

As can be appreciated by the data so far, the initial conditions of the members of Groups A and B were very similar, except for their educational level. Nonetheless, their education showed no correlation or a very weak one with the variables we will use further on to measure the wellbeing shown by the migrant towards the population and their host region or area (see below, regression analysis by steps).

\section{From Theory to Practice. Does the Model Work?}

It is important for the objectives of our work that 9 people from Group A indicated that since they began their study of Spanish, they had fewer integration problems in contrast with only 3 informants who chose the same answer in Group B. This part of our data may turn out to be very significative because until the implementation of the proximity model in March 2018, the learning conditions of both groups were the same: identical language learning procedures in so far as contents, teaching and methods (at any rate, without the systematic employment of the Proximity lexicon as a working tool). In Group B, only 2 people stated they had no integration problems in contrast with 7 who chose the same option in Group A. Likewise, we believe that data in Table 7 are relevant because we could interpret that the teaching method based on the Proximity lexicon as we propose it, could have some incidence on the social integration ease of the immigrants in the local communities.

Table 7. Integration difficulties with Malaganians *.

\begin{tabular}{|c|c|c|c|c|c|c|c|}
\hline & & \multicolumn{5}{|c|}{ Integration Difficulties with Malaganians } & \multirow[t]{2}{*}{ Total } \\
\hline & & 0 & 1 & 2 & 3 & 4 & \\
\hline & Group A & 7 & 9 & 0 & 3 & 1 & 20 \\
\hline & Group B & 2 & 3 & 8 & 6 & 1 & 20 \\
\hline Total & & 9 & 12 & 8 & 9 & 2 & 40 \\
\hline
\end{tabular}

0: I have no problems. 1: Since I study Spanish, it is easier for me to integrate. 2: No. I do not look for this type of contacts. 3: No. I just prefer to be with people who share my culture. 4: Yes, I have many problems to integrate. * Data obtained from the answers to question number 25 in the questionnaire.

Notice how 8 members of Group B did not even look for contacts; no member of Group A chose this option. Besides, the number of people from Group B $(N=6)$ doubles that of those in Group A $(\mathrm{N}=3)$ who prefer to be with members of the same culture. In Group A, we find 16 people who state they have no integration problems or that they have been reduced since they study Spanish (options 0 $+1, \mathrm{~N}=16$ ) in contrast with only 5 in Group B.

When we analyse the answers referring to students' integration with Malaga values and customs, the answers pointed in the same direction as shown in Table 8. 
Table 8. Integration in Malaga society *.

\begin{tabular}{cccccccc}
\hline & \multicolumn{4}{c}{ Degree of Integration in Malaga } & \multirow{2}{*}{ Total } \\
\cline { 3 - 6 } & None & Very Little & Little & Enough & Quite a Lot & \\
\hline \multirow{3}{*}{ Group A } & 0 & 3 & 11 & 5 & 1 & 20 \\
& Group B & 3 & 6 & 10 & 1 & 0 & 20 \\
\hline Total & 3 & 9 & 21 & 6 & 1 & 40 \\
\hline \multicolumn{7}{c}{} \\
\end{tabular}

By adding the answers to None and Very little we observe that 9 people belong to Group B and only 3 to Group A (besides, in this group, nobody chose the option None). Additionally, 6 members of Group A indicated that they were between Enough and Quite a lot integrated in the Malaga society and only 1 person from Group B agreed with that position.

With regard to the migrants' intentions in the short and the medium term, the data again consolidate the tendencies indicated: the members of Group A are the ones who in the majority consider, as a probable option, to remain in Malaga both in the short term (less than 5 years: Group $\mathrm{A}=6$; Group $\mathrm{B}=1$ ) as well as in the medium one (more than 5 years: Group $\mathrm{A}=5$; Group $\mathrm{B}=0$ ). Nevertheless, the truth is that most of the migrants we have studied, either do not know what they will do in the short/medium term or have in mind to go to some other countries.

We have left for the end of our analysis some of the items which in our opinion, will be the most useful in the evaluation of the efficacy of the proposed teaching model based on the proximity lexicon as a social integrational tool. We are referring to the gradation migrants make of (A) their feelings towards the assertions shown in items 39-41 of our questionnaire (Tables 9-11) and (B) their level of wellbeing in Malaga (Table 12, item 42 of the questionnaire). To evaluate these 4 items, the informants had to place them in a continuous scale from less to more (0-6).

Table 9. Effect of the learning group in the subjective evaluation of life in Malaga *.

\begin{tabular}{ccccccc}
\hline & & \multicolumn{2}{c}{ In the Majority of Things, My Life in Malaga Is Positive } & \multirow{2}{*}{ Total } \\
\cline { 3 - 6 } & $\mathbf{0}$ & $\mathbf{1}$ & $\mathbf{2}$ & $\mathbf{3}$ & \\
\hline \multirow{3}{*}{ Group A } & 2 & 5 & 8 & 5 & 20 \\
& Group B & 7 & 9 & 4 & 0 & 20 \\
\hline \multirow{2}{*}{ Total } & 9 & 14 & 12 & 5 & 40 \\
\hline
\end{tabular}

${ }^{*}$ Data from the answers to question number 39 in the questionnaire.

Table 10. Effect of the learning group on the subjective evaluation of life in Malaga.

\begin{tabular}{llc}
\hline & & Positive Evaluation of Life in Malaga \\
\hline \multirow{2}{*}{ Group A } & Mean & 2.8000 \\
& Typ. Dev. & 0.95145 \\
\hline \multirow{2}{*}{ Group B } & Mean & 1.8500 \\
& Typ. Dev. & 0.74516 \\
\hline Total Mean & & 2.3250 \\
Typ. dev. & & 0.85342 \\
\hline
\end{tabular}

Sig. 0.001 
Table 11. Effect of the learning group in the subjective evaluation of life conditions in Malaga *.

\begin{tabular}{ccccccc}
\hline & & \multicolumn{4}{c}{ My life Conditions in Malaga Are Adequate } & \multirow{2}{*}{ Total } \\
\cline { 3 - 6 } & $\mathbf{0}$ & $\mathbf{1}$ & $\mathbf{2}$ & $\mathbf{3}$ & \\
\hline & Group A & 2 & 4 & 12 & 2 & 20 \\
& Group B & 16 & 4 & 0 & 0 & 20 \\
\hline Total & 18 & 8 & 12 & 2 & 40 \\
\hline \multicolumn{3}{c}{} & & $*$ Data obtained from answers to question number 40 in the questionnaire.
\end{tabular}

Table 12. Effect on the learning group on the subjective evaluation of life conditions in Malaga.

\begin{tabular}{llc}
\hline & & $\begin{array}{c}\text { Subjective Evaluation of Life } \\
\text { Conditions in Malaga }\end{array}$ \\
\hline \multirow{2}{*}{ Group A } & Mean & 2.7000 \\
& Typ. Dev. & 0.80131 \\
\hline \multirow{2}{*}{ Group B } & Mean & 1.2000 \\
& Typ. Dev. & 0.41039 \\
\hline \multirow{2}{*}{ Total } & Mean & 1.9500 \\
& Typ. Dev. & 0.67436 \\
\hline
\end{tabular}

Sig. 0.000

The only grade 3 evaluations shown in Table 9 belong to Group A subjects $(\mathrm{N}=5)$; notice that 16 people from Group B chose the lower levels of the scale (grades 0 and 1) in contrast to 7 of Group A. Additionally, only 4 people from Group B chose option 2, which was half of those in Group A (N = 8).

The media analysis shows a weak signification index, although with an $\mathrm{Eta}^{2}$ of low intensity (Table 10).

The Mann-Whitney test was applied for differences of means in independent samples

\begin{tabular}{lcc}
\hline Measures of Association & Eta & Eta $^{2}$ \\
Group * Positive Evaluation of life in Malaga & 0.506 & 0.256 \\
\hline
\end{tabular}

Similar tendencies are observed when analysing the data from the evaluation of life conditions in Malaga (Table 11). Nevertheless, on this occasion, the values of the means and the measures of association are very significative (Table 12). It calls our attention that all members of Group B chose the lowest proposed grades $(\mathrm{N}=20$, grades 0 and 1). Only 6 people from Group A opted for the same levels, in contrast with the 14, who chose 2 or 3.

The Mann-Whitney test was applied for mean differences in independent samples

\begin{tabular}{ccc}
\hline Measures of Association & Eta & Eta $^{2}$ \\
Group * Sentence2 & 0.789 & 0.622 \\
\hline
\end{tabular}

To think of moving dear relatives to a new country to start a new life is a very difficult decision, which requires a high degree of certainty and determination. However, as can be observed (Table 13) most of the subjects in Group A chose the highest option in this aspect (grade 2, N = 18), while the 20 subjects of Group B chose option $0(\mathrm{~N}=16)$ or $1(\mathrm{~N}=4)$. Nobody in this group chose option 3 in contrast with 1 person in Group A. 
Table 13. Effect of the learning group on expectations of moving the family to Malaga.

\begin{tabular}{|c|c|c|c|c|c|c|}
\hline & & \multicolumn{4}{|c|}{ If It Depended on me, I Would Bring My Family to Malaga } & \multirow{2}{*}{ Total } \\
\hline & & 0 & 1 & 2 & 3 & \\
\hline & Group A & 0 & 1 & 18 & 1 & 20 \\
\hline & Group B & 16 & 4 & 0 & 0 & 20 \\
\hline Total & & 16 & 5 & 18 & 1 & 40 \\
\hline
\end{tabular}

The strong signification values obtained from the media analysis led to a possible positive effect of the proposed teaching model (Table 14).

Table 14. Expectations of moving the family to Malaga.

\begin{tabular}{llc}
\hline Group A & Mean & $\begin{array}{c}\text { Expectations of Moving } \\
\text { the Family to Malaga }\end{array}$ \\
& Typ. Dev. & 3.0000 \\
Group B & Mean & 0.32444 \\
& Typ. Dev. & 1.2000 \\
\multirow{2}{*}{ Total } & Mean & 0.41039 \\
& Typ. Dev. & 2.1000 \\
& \multicolumn{2}{c}{ Sig. 0.000} \\
\hline
\end{tabular}

The Mann-Whitney test was applied for the media differences in independent samples

\begin{tabular}{lcc}
\hline Measures of association & Eta & Eta $^{2}$ \\
Group * Expectations of moving the family to Malaga & 0.959 & 0.920 \\
\hline
\end{tabular}

Table 15 shows very similar results, although in this occasion, the tendency towards a more positive evaluation of wellbeing in Malaga seems even more evident among members of Group A. Nobody in Group B indicated grade 4 and only one chose option 3. This option was selected by 6 members of Group A, who also indicated their preference for option 4 three times. More than half of the subjects of Group B opted for the lower grades of the scale ( 0 or $1, N=15)$ while only 6 did the same in Group A.

Table 15. Effect of the learning group on the general level of wellbeing in Malaga *.

\begin{tabular}{cccccccc}
\hline & \multicolumn{5}{c}{ General Level of Wellbeing in Malaga } & \multirow{2}{*}{ Total } \\
\cline { 3 - 7 } & & $\mathbf{0}$ & $\mathbf{1}$ & $\mathbf{2}$ & $\mathbf{3}$ & $\mathbf{4}$ & \\
\hline \multirow{3}{*}{ Group A } & 2 & 4 & 5 & 6 & 3 & 20 \\
& Group B & 4 & 11 & 4 & 1 & 0 & 20 \\
\hline Total & 6 & 15 & 9 & 7 & 3 & 40 \\
\hline
\end{tabular}

${ }^{*}$ Data obtained from the answers to question number 42 of the questionnaire.

As Table 16 shows, the signification and association measures were more moderate in this case. 
Table 16. Effect of the learning group on the sensation of general wellbeing.

\begin{tabular}{llc}
\hline & & General Wellbeing \\
\hline \multirow{2}{*}{ Group A } & Mean & 3.2000 \\
& Typ. Dev. & 1.23969 \\
\hline \multirow{2}{*}{ Group B } & Mean & 2.1000 \\
& Typ. Dev. & 0.78807 \\
\hline \multirow{2}{*}{ Total } & Media & 2.6500 \\
& Typ. Dev. & 0.98976 \\
\hline & & Sig. 0.026 \\
\end{tabular}

The Mann-Whitney test was applied for media differences in independent samples

\begin{tabular}{ccc}
\hline Measures of association & Eta & $\mathrm{Eta}^{2}$ \\
Group * Wellbeing in Malaga & 0.515 & 0.265 \\
\hline
\end{tabular}

The signification index of the positive correlations in Table 17 is high enough in all cases so that the belonging to learning groups can be considered a relevant explanatory factor of the variables that measure the migrants' degree of wellbeing in their host community. The form of the variables correlated in Table 17 were recodified on the basis of a fictitious variable in which Group $B=0$ and Group A $=1$. Variables Sentence 1, Sentence 2, Sentence 3 and Wellbeing in Malaga were measured on a scale of gradation from 0 (completely in disagreement) to 6 (completely in agreement).

Table 17. Learning group and wellbeing indicators. Spearman correlations.

\begin{tabular}{|c|c|c|c|c|}
\hline & Sentence 1 & Sentence 2 & Sentence 3 & $\begin{array}{c}\text { Wellbeing in } \\
\text { Malaga }\end{array}$ \\
\hline \multirow[t]{2}{*}{ Group } & $0.491(* *)$ & $0.778\left(^{* *}\right)$ & $0.934(* *)$ & $0.468(* *)$ \\
\hline & Sig. 0.001 & Sig. 0.000 & Sig. 0.000 & Sig. 0.002 \\
\hline & ** The cor & $\begin{array}{l}\mathrm{N}=40 \\
\text { significative }\end{array}$ & vel of 0.01 & \\
\hline
\end{tabular}

Sentence 1: In most things, my life in Malaga is positive

Sentence 2: The conditions of my life are adequate

Sentence 3: If it depended on me, I would bring my family to live in Malaga

At the end, we made a recodification of some of the items of the questionnaire, whose scales were compatible and from them, two new variables were made in order to measure: (1) the informant's global subjective satisfaction (Individual Subjective Satisfaction, ISS) and (2) the individual sensation of general wellbeing (General Wellbeing Index, GWI).

The first case deals with the original questionnaire variables, which measure on a scale from minor to major ( 1 to 5 ) the integration and opening of the analysed migrants to the host region and its inhabitants. Variable 25 was recodified to adapt it to the new scale.

\section{You have meetings in your free time}

1. Only with members of my family

2. Only with people of my origin or culture

3. Never with people of my origin or culture, except with Spaniards

4. With every type of people, including Spaniards

\section{You participate in associations or groups in free time}


1. No

2. Yes, only with people of my origin or culture

3. Yes, but never with people of my origin or culture

4. Yes, with every type of people, except with Spaniards

5. Yes, with every type of people, including Spaniards

25. Do you have difficulties to integrate with Malaganians or groups of them? Think, for example. if you feel comfortable when you are with these people and consider you an equal or if, on the contrary, when you are with these people you feel a foreigner

1. Yes, I have many difficulties to integrate

2. No, but I only prefer to be with people of my zone or culture

3. No, I do not look for this type of contact

4. Since I study Spanish I find it easier to integrate

5. I do not have any problems

28. How do you evaluate the native population of Malaga?

1. Very negatively

2. Negatively

3. I am indifferent towards them

4. Positively

5. Very positively

31. In what way do you feel integrated with the customs of the Malaga society? (traditions like Easter, Carnival, etc.)

1. Not at all

2. Very little

3. Little

4. Enough

5. Quite a lot

33. What are your intentions now?

1. To make money and go back in less than a year

2. To make money to build a better life in my country of origin

3. To start a new life in another country

4. To go back and stay with my family

5. To stay in Malaga

34. What do you think you will do in the next 5 years?

1. Going back to my country

2. Moving to another country

3. Moving to another Spanish autonomous community

4. Moving to another city in Andalusia

5. Staying in Malaga

35. What do you think of doing after the next 5 years? (As a life project)

1. Going back to my country 
2. Moving to another country

3. Moving to another Spanish autonomous community

4. Moving to another city of Andalusia

5. Staying in Malaga

The resulting variable of the reformulation of the previous ones (ISS calculated as a function of the number of times informants opted for the values of the scale 1-5 in all the considered variables) showed a normal distribution with some differences of means of a low potency (Table 18).

Table 18. Effect of the learning group in the Individual Subjective Sensation (ISS).

\begin{tabular}{llcc}
\hline & & ISS & Punctuation Z \\
\hline \multirow{2}{*}{ Group A } & Mean & 3.9500 & 0.5071618 \\
& Typ. Dev. & 1.46808 & 0.91260825 \\
\hline \multirow{2}{*}{ Group B } & Mean & 2.0500 & -0.3631248 \\
& Typ. Dev. & 1.05006 & 0.65275386 \\
\hline \multirow{2}{*}{ Total } & Mean & 3.2500 & 0.0720185 \\
& Typ. Dev. & 1.44559 & 0.89862964 \\
\hline
\end{tabular}

Sig. 0.001

The Mann-Whitney test was applied for the differences of means in independent samples

\begin{tabular}{lcc}
\hline Measures of association & Eta & $\mathrm{Eta}^{2}$ \\
ISS * Group & 0.490 & 0.240 \\
Z punctuation (ISS) * Group & 0.490 & 0.240 \\
\hline
\end{tabular}

The second recodification was done from the individual original variables, which measured on a 0-6 scale certain wellbeing parameters related to the informants's stay in Malaga (variables 39-42 in the questionnaire). In this occasion, the new recodified scale in three levels of intervals according to the informants' original answers $(0-2=$ Level $0 ; 3=$ Level $1 ; 4-6=$ Level 2$)$. The differences of means show results of very high significance, now with values de $\mathrm{Eta}^{2}$ of high potency (Table 19).

Table 19. Effect of the learning group in the General Wellbeing (GWI).

\begin{tabular}{lcc}
\hline GWI & Mean & Typ. Dev. \\
\hline Group A & 1.9500 & 0.22361 \\
Group B & 1.0000 & 0.00000 \\
Total & 1.4750 & 0.50574 \\
\hline
\end{tabular}

The Mann-Whitney test was applied for differences of means in independent samples

\begin{tabular}{ccc}
\hline \multicolumn{3}{c}{ Measures of Association } \\
\hline GWI * Group & Eta & Eta $^{2}$ \\
& 0.872 & 0.761 \\
\hline
\end{tabular}

Test of independent samples 


\begin{tabular}{lllllllll}
\hline \multirow{2}{*}{ GWI } & \multicolumn{3}{c}{$\begin{array}{c}\text { Levene Test for } \\
\text { Equality of Variances }\end{array}$} & \multicolumn{3}{c}{ T test for the Equality of Variances } \\
\cline { 2 - 7 } & F & Sig. & $\mathbf{t}$ & df & $\begin{array}{c}\text { Bilateral } \\
\text { Sig. }\end{array}$ & $\begin{array}{c}\text { Differences of } \\
\text { Means }\end{array}$ \\
\hline $\begin{array}{l}\text { Equal variances } \\
\text { have been assumed }\end{array}$ & 4.457 & 0.041 & -19.000 & 38 & 0.000 & -0.95000 \\
\hline $\begin{array}{l}\text { Equal variances } \\
\text { have not been } \\
\text { assumed }\end{array}$ & & & & -19.000 & 19.000 & 0.000 & -0.95000 \\
\hline
\end{tabular}

Our significative results, and a final analysis of regression by steps, helped us to design a statistical model, which confirms: (1) the high correlation observed between group belonging and the variable GWI and (2) the weak correlation between the variables gender and education and the dependent variable (GWI, both variables were excluded from the model, Table 20). Thus, we discarded that the internal group imbalance with regard to the educational level of their members (Tables 5 and 6) was camouflaging a possible covert effect of this variable on the results.

Table 20. Regression analysis.

\begin{tabular}{|c|c|c|c|}
\hline \multicolumn{4}{|c|}{ Introduced/Eliminated Variables } \\
\hline Model & Introduced Variables & Eliminated Variables & Method \\
\hline 1 & Group & Gender Education & $\begin{array}{l}\text { By steps (criterion: Prob. of } F \text { to } \\
\text { enter }<=0.050 \text {. Prob. of } F \text { to leave } \\
>=0.100) .\end{array}$ \\
\hline
\end{tabular}

Dependent Variable: IBG.

\begin{tabular}{|c|c|c|c|c|c|c|c|c|}
\hline \multicolumn{9}{|c|}{ Eliminated Variables } \\
\hline \multirow{2}{*}{\multicolumn{2}{|c|}{ Model }} & \multirow[b]{2}{*}{ Beta in } & \multirow[b]{2}{*}{$\mathbf{t}$} & \multirow[b]{2}{*}{ Sig. } & \multirow[b]{2}{*}{$\begin{array}{c}\text { Partial } \\
\text { Correlation }\end{array}$} & \multicolumn{3}{|c|}{ Colinearity Statistics } \\
\hline & & & & & & Tolerance & VIF & $\begin{array}{l}\text { Minimal } \\
\text { Tolerance }\end{array}$ \\
\hline \multirow{2}{*}{1} & Gender & $0.041^{\mathrm{b}}$ & 0.813 & 0.422 & 0.132 & 1.000 & 1.000 & 1.000 \\
\hline & $\begin{array}{l}\text { Recodified } \\
\text { Education }\end{array}$ & $-0.029^{b}$ & -0.536 & 0.595 & -0.088 & 0.875 & 1.143 & 0.875 \\
\hline
\end{tabular}

Dependent Variable: GWI. ${ }^{\mathrm{b}}$ Predictors in the model: (Constant), Group.

\begin{tabular}{cccccc}
\hline \multicolumn{6}{c}{ Summary of the Model } \\
\hline Model & $\mathbf{R}$ & R Square & $\begin{array}{c}\text { Corrected R } \\
\text { Square }\end{array}$ & $\begin{array}{c}\text { Standard Error } \\
\text { in the Estimate }\end{array}$ & Durbin-Watson \\
\hline 1 & $0.951^{\text {a }}$ & 0.905 & 0.902 & 0.15811 & 2.108 \\
\hline \multicolumn{4}{r}{ a Predictors: (Constant), Group. Dependent Variable: GWI. }
\end{tabular}

\begin{tabular}{|c|c|c|c|c|c|c|}
\hline \multicolumn{7}{|c|}{ ANOVA $^{a}$} \\
\hline & Model & $\begin{array}{l}\text { Sum of } \\
\text { Squares }\end{array}$ & df & $\begin{array}{l}\text { Mean } \\
\text { Square }\end{array}$ & F & Sig. \\
\hline \multirow{3}{*}{1} & Regression & 9.025 & 1 & 9.025 & 361,000 & $0.000^{b}$ \\
\hline & Residual & 0.950 & 38 & 0.025 & & \\
\hline & Total & 9.975 & 39 & & & \\
\hline
\end{tabular}

${ }^{a}$ Dependent Variable: GWI, ${ }^{b}$ Predictors: (Constant), Group. 


\begin{tabular}{ccccccc}
\hline \multicolumn{8}{c}{ Coefficients } \\
\hline \multirow{2}{*}{ Model } & \multicolumn{2}{c}{ Non-Standardised Coefficients } & $\begin{array}{c}\text { Typified } \\
\text { Coefficients }\end{array}$ & T & Sig. \\
\cline { 3 - 5 } & B & Standard Error & Beta & & \\
\hline \multirow{2}{*}{1} & (Constant) & 1.000 & 0.035 & & 28.284 & 0.000 \\
& Group & 0.950 & 0.050 & 0.951 & 19.000 & 0.000 \\
\hline
\end{tabular}

Dependent Variable: GWI.

\section{Discussion and Final Reflections}

One of the major obstacles migrants have when they arrive at their destinations is their lack of knowledge of the local language and customs of the countries chosen for settlement. Nonetheless, in this work we have aimed at transforming this difficulty into the possibility of providing a better adaptation by way of a linguistic learning model backed by the following fundamentals, a consequence of what we have exposed so far:

1. There is an objective need to formulate proposals leading to the successful sociocultural integration of immigrants (particularly the more unprotected and vulnerable among them) from the language classrooms.

2. The challenge consists of supplying the lack of linguistic knowledge with inclusive programmes which, with respect to the nearest traditions, manage to promote the immigrants' sociocultural integration in a multidimensional way and their acceptance by the host communities

3. Consequently, it is a question of promoting educational programmes based on respect for the rights of the more vulnerable groups, which also deepens mutual understanding and acceptance of cultures and values of both the host communities and of the immigrant groups.

4. Language has proved to be a powerful social connection between groups enjoying equality and that fact has been fully recognised by the main international institutions, which observe and study population and migratory flows (OECD/European Union 2015; Helke and Laczko 2015; Jahan 2016). Language teaching models should be adapted to include effective elements that facilitate this integration.

5. Social dialectology is aware of a dynamic convergence process which is generalised among varieties of the same language (Auer 2005; Auer et al. 2005; Hinskens 1996; Kerswill 2003; Trudgill 2002; Villena 2005, among many others). This process strengthens the idea-widely accepted in the foreign language teaching field —of employing the standard variety as the basis of learning. However, the divergence processes play an important role not to be underestimated (Braunmüller et al. 2014; Villena and Vida 2017): the divergent variants reinforce the social solidarity links and can be used as integration tools when working with vulnerable groups (Ávila-Muñoz Forthcoming).

6. Our proposal is compatible with the usual native and foreign language teaching processes. While complementing already elaborated didactic units, it could be also employed in the preparation of new ones. As the proximity vocabulary is restricted, the selection of the more adequate ones for each didactic unit will depend on each specific situation. The teachers are in charge of selecting and adding the relevant dialectal lexical elements to be introduced in the classroom gradually and adequately. The selection would have to be preceded by a study of the particular characteristics of each lexical units of the area for which glossaries and specialised dictionaries should be consulted. Furthermore, this study could also come from the knowledge teachers have of the sociolinguistic reality of the area in which they work. It is a question of trying to adjust the lexical selection to the model of concentrical crowns in each case as suggested in our proposal: 
a. Inclusion of the proximity lexicon associated to specific thematic units or communication spaces when sufficient material exists. In these cases, the proximity vocabulary is to be presented and structured according to the model of concentrical crowns model, with a nucleus formed by extensively used and recognised elements in the local community-and thus, with a strong connoted value of social integration and group belonging conscience-it would be used at the most elementary: A2-B1 or Lower Intermediate-Intermediate for foreign language teaching; primary education in the case of the general teaching regime. In the higher levels, less-used vocabulary could be introduced in the speech community, although with the same social cohesion function.

b. Should the number of lexical elements be insufficient to execute the proposal as structure in concrete didactic units, the teacher should appeal to the general model of lexical selection (frequent lexicon, lexical availability, proximity lexicon) and include dialectal elements from the peripheral crown containing units with the required social integration function.

c. Lastly, the use of the proximity lexicon in the language classroom facilitates the realisation of complementary practical activities (workshops, informal meetings, debates), which may prove attractive to the students.

The results which have been shown in this paper after the implementation of the proposed model with a group of migrants as students of SFL, give room great hope. If we compare the results from the wellbeing questionnaire as answered by students after the end of the course according to our model with the answers of the members of the control group-who as such were not asked to do that course-we can assert that the model seems to work. Those who enjoyed the course with our model, showed a significantly higher degree of social integration, personal wellbeing and subjective satisfaction than those who followed a different methodology. The former are individuals with a more positive perception of their life conditions in their host community than the members of the control group, to the point that they even plan to bring their relatives to their actual location. This very positive attitude envisages commencing a new life in Malaga together with their family, which definitely indicates a considerably greater index of general well-being.

Summing up we can assert that we have created a foreign language teaching programme for migrant populations from the basis of a deep knowledge of the difficulties for the social integration of these groups. This programme justifies the use of the proximity lexicon in the language classroom as a sociocultural integration tool for migrant populations, but above all, for the more unprotected groups, who may find the employment of the proximity lexicon an entertaining and flexible manner to attain inclusion in the community. Although it is true that teachers may have appealed to these strategies previously in a more or less sporadic and unsystematic manner, from this point onwards, a collective space for discussion and work has been created, which justifies, structures, endorses and recommends this practice.

Funding: This research was funded by DGICYT, grant number FFI2015-68171-C5-1-P.

Acknowledgments: This research was supported by DGICYT: Estudio Complementario de los Patrones sociolingüísticos del Español de Málaga (FFI2015-68171-C5-1-P).

Conflicts of Interest: The author declares no conflict of interest.

\section{Appendix A. Sociological Questionnaire of Wellbeing}

Subject number:

1. Gender

1. MALE

2. FEMALE 


\section{Age in years}

\section{Native country}

\section{Year of arrival in Spain}

\section{Year of arrival in Andalusia}

\section{Year of arrival in Malaga}

\section{Completed studies}

0. Subject did not attend school

1. None, although (s)he attended school

2. Primary

3. Secondary

4. Professional

5. University

\begin{tabular}{|c|c|}
\hline $\begin{array}{l}\text { 8. Do you keep in contact with your relatives in } \\
\text { your native country? }\end{array}$ & 9. How frequently?? \\
\hline 0. Never & 0. Very sporadically \\
\hline 1. Yes, by mail & 1. Once a month \\
\hline 2. Yes, by videoconference & 2. More than twice a month \\
\hline 3. Yes, by Internet (e-mail, chat, Skype ... ) & 3. Twice or more times a week \\
\hline 4. Yes, by telephone & 4. Every day \\
\hline
\end{tabular}

Degree of satisfaction with the following aspects of your work at present or the last one you had in Spain. (If you have had no work, continue with question 22) 


\begin{tabular}{|c|c|c|c|c|c|}
\hline & $\begin{array}{c}\text { Very } \\
\text { Unsatisfied }\end{array}$ & Little Satisfied & $\begin{array}{l}\text { Satisfied } \\
\text { Enough }\end{array}$ & Very Satisfied & $\begin{array}{l}\text { Do Not Know. } \\
\text { No Answer }\end{array}$ \\
\hline 10. The type of work you do & 1 & 2 & 3 & 4 & \\
\hline 11. The position you have & 1 & 2 & 3 & 4 & \\
\hline $\begin{array}{l}\text { 12. Possibilities of } \\
\text { promotion }\end{array}$ & 1 & 2 & 3 & 4 & \\
\hline 13. Timetable & 1 & 2 & 3 & 4 & \\
\hline $\begin{array}{l}\text { 14. Relation with bosses or } \\
\text { superiors }\end{array}$ & 1 & 2 & 3 & 4 & \\
\hline 15. Rhythm & 1 & 2 & 3 & 4 & \\
\hline 16. Working conditions & 1 & 2 & 3 & 4 & \\
\hline $\begin{array}{l}\text { 17. Degree of harshness of } \\
\text { work }\end{array}$ & 1 & 2 & 3 & 4 & \\
\hline 18. Level of risks & 1 & 2 & 3 & 4 & \\
\hline $\begin{array}{l}\text { 19. Psychological pressure } \\
\text { caused by work }\end{array}$ & 1 & 2 & 3 & 4 & \\
\hline 20. Income & 1 & 2 & 3 & 4 & \\
\hline $\begin{array}{l}\text { 21. Adjustment to your life } \\
\text { according to culture and } \\
\text { religion }\end{array}$ & 1 & 2 & 3 & 4 & \\
\hline $\begin{array}{l}\text { 22. Does it adjust to your } \\
\text { studies? }\end{array}$ & 1 & 2 & 3 & 4 & \\
\hline
\end{tabular}

\begin{tabular}{|c|c|}
\hline 23. Who do you meet in your free time? & 24. Participation in associations or free time groups \\
\hline 1. Only with members of my family & No \\
\hline $\begin{array}{l}\text { 2. Only with people of my native country or } \\
\text { my culture }\end{array}$ & $\begin{array}{l}\text { 2. Yes, only with people of my native country } \\
\text { or culture }\end{array}$ \\
\hline $\begin{array}{l}\text { 3. Never with people of my native country } \\
\text { or culture }\end{array}$ & $\begin{array}{l}\text { 3. Yes, but never with people of my native country } \\
\text { or culture }\end{array}$ \\
\hline $\begin{array}{l}\text { 4. With every type of people, except } \\
\text { with Spaniards }\end{array}$ & $\begin{array}{l}\text { 4. Yes, with every type of people, except } \\
\text { with Spaniards }\end{array}$ \\
\hline 5. With very type of people, including Spaniards & $\begin{array}{l}\text { 5. Yes, with all types of people, } \\
\text { including Spaniards }\end{array}$ \\
\hline
\end{tabular}

\begin{tabular}{|c|c|}
\hline $\begin{array}{l}\text { 25. Do you have difficulties to integrate? Do you } \\
\text { have difficulties to integrate with Malaganians or } \\
\text { groups of them? Think for example if you feel } \\
\text { comfortable with these people and consider } \\
\text { youself as an equal or on the contrary, when you } \\
\text { are with them, you feel a foreigner }\end{array}$ & $\begin{array}{l}\text { 26. Do you have difficulties to integrate with } \\
\text { people or groups of immigrants? }\end{array}$ \\
\hline $\begin{array}{l}\text { 0. I do not have a problem } \\
\text { 1. Since I study Spanish, it is easier to integrate } \\
\text { 2. No, I do not look for this type of contacts } \\
\text { 3. No, but I prefer to be with people from my area } \\
\text { or culture } \\
\text { 4. Yes, I have many difficulties to integrate }\end{array}$ & $\begin{array}{l}\text { 0. I do not have problems. } \\
\text { 1. No, I do not look for that type of contacts } \\
\text { 2. No, but I only prefer to be with people from my } \\
\text { area or culture } \\
\text { 3. Yes, I have many difficulties to integrate }\end{array}$ \\
\hline
\end{tabular}


27. Do you participate or are affiliated or registered in associations or groups?

0. No

1. Informal groups of immigrants

2. Organisations of support

3. Associations or sport clubs

4. Educational or sport groups

5. Religious entities or groups

6. Neighbourhood groups

7. Labour unions

8. Political parties

9. Brotherhoods, confraternities, coteries

\begin{tabular}{|c|c|}
\hline $\begin{array}{l}\text { 28. How do you evaluate the Malaga native } \\
\text { population? }\end{array}$ & $\begin{array}{l}\text { 29. How do you evaluate the immigrant population } \\
\text { resident in Malaga? }\end{array}$ \\
\hline Very negatively & Very negatively \\
\hline Negatively & 2. Negatively \\
\hline Indifferent towards them & Indifferent towards them \\
\hline Positively & 4. Positively \\
\hline 5. Very positively & 5. Very positively \\
\hline
\end{tabular}

\begin{tabular}{|c|c|c|c|c|}
\hline \multicolumn{4}{|c|}{ 30. Have you experienced incidents in Malaga related to } & $\begin{array}{l}\text { 31. To what degree do you } \\
\text { feel integrated into } \\
\text { customs in Malaga society? } \\
\text { (traditions such as Easter, } \\
\text { carnival, the fair, etc.?) }\end{array}$ \\
\hline $\begin{array}{l}\text { Racism/xenofobia? } \\
\text { Describe the } \\
\text { incidents: }\end{array}$ & $\begin{array}{l}\text { Grave } \\
2\end{array}$ & $\begin{array}{l}\text { Not grave } \\
1\end{array}$ & $\begin{array}{l}\text { No } \\
0\end{array}$ & $\begin{array}{ll}\text { 1. } & \text { Not at all } \\
\text { 2. } & \text { Very little } \\
\text { 3. } & \text { Little } \\
\text { 4. } & \text { Enough } \\
\text { 5. } & \text { Quite a lot }\end{array}$ \\
\hline
\end{tabular}

\section{What were your intentions}

\begin{tabular}{|c|c|}
\hline 32. When you started your trip? & 33. Now? \\
\hline $\begin{array}{l}\text { 1. To make money and return in less than a year } \\
\text { 2. To make money to build a better life in my } \\
\text { native country } \\
\text { 3. To start a new life in another country } \\
\text { 4. To go back to the company of my family }\end{array}$ & $\begin{array}{l}\text { 1. To make money and return in less than a year } \\
\text { 2. To make money and build a better life in my } \\
\text { 3. To start a new life in another country } \\
\text { 4. To be in the company of my family } \\
\text { 5. To stay in Malaga }\end{array}$ \\
\hline
\end{tabular}

What do you think you will do 


\begin{tabular}{|lccccc|}
\hline & $\begin{array}{c}\text { Going back to } \\
\text { my country }\end{array}$ & $\begin{array}{c}\text { Moving to } \\
\text { another } \\
\text { country }\end{array}$ & $\begin{array}{c}\text { Moving to } \\
\text { another } \\
\text { Autonomous } \\
\text { Community in } \\
\text { Spain }\end{array}$ & $\begin{array}{c}\text { Moving to } \\
\text { another } \\
\text { Andalusian } \\
\text { city }\end{array}$ & $\begin{array}{c}\text { Staying in } \\
\text { Malaga }\end{array}$ \\
\hline $\begin{array}{l}\text { 34. In the next } \\
\text { 5 years? }\end{array}$ & 1 & 2 & 3 & 4 & 5 \\
\hline $\begin{array}{l}\text { 35. Beyond 5 } \\
\text { years, as a life } \\
\text { project? }\end{array}$ & 1 & 2 & 3 & 4 & 5 \\
\hline
\end{tabular}

Expectations of those who think of staying in Malaga for the next 5 years or beyond:

\begin{tabular}{|c|c|c|}
\hline 36. Dwelling & 37. Employment & 38. Social relations \\
\hline $\begin{array}{ll}\text { 1. } & \text { To stay in my } \\
\text { actual dwelling } \\
\text { 2. } & \text { Share another dwellling } \\
\text { 3. } & \text { Rent a a dwelling } \\
\text { 4. } & \text { To finish paying my } \\
& \text { actual dwelling }\end{array}$ & $\begin{array}{ll}\text { 1. To continue as until now } \\
\text { 2. To find employment } \\
\text { (whichever I find) } \\
\text { 3. To find stable employment } \\
\text { 4. To find employment in a } \\
\text { different sector or activity } \\
\text { 5. To find employment } \\
\text { according to my formation }\end{array}$ & $\begin{array}{l}\text { 1. To continue as until now } \\
\text { 2. To relate myself more with } \\
\text { people of my area or culture } \\
\text { 3. To relate myself more } \\
\text { with Malaganians } \\
\text { 4. To distance myself from } \\
\quad \text { people of my area or culture }\end{array}$ \\
\hline
\end{tabular}

The following five sentences reflect how people can think and feel about their life. By way of the following scale from 0 (completely in disagreement) to 6 (completely in agreement), indicate sincerely at what point of your life you find yourself and how you feel about it.

\begin{tabular}{|c|c|c|c|c|c|c|c|c|}
\hline 39 & $\begin{array}{l}\text { In most things, my life in Malaga is } \\
\text { positive }\end{array}$ & 0 & 1 & 2 & 3 & 4 & 5 & 6 \\
\hline 40 & $\begin{array}{l}\text { The conditions of my life in Malaga } \\
\text { are adequate }\end{array}$ & 0 & 1 & 2 & 3 & 4 & 5 & 6 \\
\hline 41 & $\begin{array}{l}\text { If it were up to me, I would bring } \\
\text { my family to live in Malaga. }\end{array}$ & 0 & 1 & 2 & 3 & 4 & 5 & 6 \\
\hline
\end{tabular}

42. What is your actual general wellbeing in Malaga? Consider, for instance, if you feel comfortable in the city, if you feel a foreigner among the people when you go out for a stroll, if you like the city and the way of being of Malaganians.

\begin{tabular}{|l|l|l|l|l|l|l|}
\hline 0 & 1 & 2 & 3 & 4 & 5 & 6 \\
\hline
\end{tabular}

\section{References}

American Council on the Teaching of Foreign Languages. 2012. Performance Descriptors for Language Learners. Alexandria: ACTFL, Available online: https:/www.actfl.org/sites/default/files/pdfs/ PerformanceDescriptorsLanguageLearners.pdf (accessed on 1 March 2019).

Ariolfo, Rosana. 2012. Actitudes lingüisticas, inmigración y escuela: Un aporte para la reflexión y la práctica educativa. Lecce: Libellula Edizioni.

Atienza, Francisco Luis, Diana Pons, Isabel Balaguer, and Marisa Garcia-Merita. 2000. Propiedades psicométricas de la escala de satisfacción con la vida en adolescentes. Psicothema 12: 331-36.

Auer, Peter. 2005. Europe's sociolinguistic unity; or: A typology of European dialect/standard constellations. In Perspectives on Variation. Edited by Nicole Delbecque, Johan van der Auwera and Dirk Geeraerts. Berlin and Nueva York: Mouton de Gruyter, pp. 7-42. 
Auer, Peter, Frans Hinskens, and Paul Kerswill, eds. 2005. Dialect Change: Convergence and Divergence in European Languages. Cambridge: Cambridge University Press.

Ávila-Muñoz, Antonio Manuel. 1999. Léxico de frecuencia del español hablado en la ciudad de Málaga. Málaga: Universidad.

Ávila-Muñoz, Antonio Manuel. 2017. Entre limonetis y malaguitas: Estudio del léxico divergente de proximidad. Nuevos datos del Proyecto CONVERLEX-Málaga. Hispania 100: 538-53. [CrossRef]

Ávila-Muñoz, Antonio Manuel, and Juan Andrés Villena Ponsoda, eds. 2010. Variación social del léxico disponible en la ciudad de Málaga. Malaga: Sarriá.

Ávila-Muñoz, Antonio Manuel. Forthcoming. La integración sociocultural de los grupos vulnerables de inmigrantes desde el aula de lenguas. Propuesta de actuación desde la dialectología social en la ciudad de Málaga. Lengua y migración/Language and Migration. Forthcoming.

Bombarelli, Ángela. 2005. La disponibilidad léxica como herramienta didáctica: una propuesta de selección del vocabulario para un nivel umbral de ELE. Degree-Granting Salamanca. Salamanca: Universidad.

Braunmüller, Kurt, Steffen Höder, and Karoline Kühl, eds. 2014. Stability and Divergence in Language Contact. Factors and Mechanisms. Amsterdam and Philadelphia: John Benjamins.

Bravo-García, Eva, Emilio Gallardo-Saborido, Inmaculada Santos de la Rosa, and Antonio Gutiérrez, eds. 2014. Investigaciones sobre la enseñanza del español y su cultura en contextos de inmigración. Helsinki: University of Helsinki, Seville: University of Seville.

CIS. 2015. Estudio número 3119. Actitudes hacia la Inmigración (VIII). Available online: http://www.cis.es/cis/opencm/ ES/1encuestas/estudios/ver.jsp?estudio=14249\&cuestionario=17109\&muestra=22655 (accessed on 1 March 2019).

Davies, Mark. 2005. A Frequency Dictionary of Spanish: Core Vocabulary for Leaners. London: Routledge.

Dempster, Helen, and Karen Hargrave. 2017. Understanding Public Attitudes towards Refugees and Migrants. London: Overseas Development Institute, Available online: http://www.odi.org/publications/10826 (accessed on 1 April 2019).

Devereaux, Michelle D., and Chris C. Palmer, eds. 2019. Teaching Language Variation in the Classroom. Strategies and Models from Teachers and Linguists. New York and London: Routledge.

Diener, Ed, Robert A. Emmons, Randy J. Larsen, and Sharon Griffin. 1985. The satisfaction with life scale. Journal of Personality Assessment 49: 71-75. [CrossRef] [PubMed]

Egli, Mirjam, and Katharina Höchle. 2016. PluriMobil meets DYLAN_Practical resources for supporting plurilingual and intercultural learning in vocational students' mobility. In Managing Plurilingual and Intercultural Practices in the Workplace. Edited by Georges Lüdi, Katharina Höchle Meier and Patchareeart Yanaprasart. Amsterdam and Philadelphia: John Benjamins, pp. 294-313.

European Council. 2002. European Common Frame of Reference for Languages. Madrid: MECD, Available online: http://crc.cervantes.es/ensenanza/biblioteca_ele/marco/ (accessed on 1 March 2019).

EUROSTAT. 2017. Statistics Explained. Estadísticas de migración y población migrante. Available online: http://ec.europa.eu/eurostat/statistics-explained/index.php/Migration_and_migrant_population_ statistics/es\#Principales_resultados_estad.C3.ADsticos (accessed on 1 March 2019).

Fernández-Vítores, David. 2013. El papel de la lengua en la configuración de la migración europea: tendencias y desencuentros. Lengua y migración/Language and Migration 5: 51-66.

Helke, Jill, and Frank Laczko. 2015. Informe sobre las migraciones en el mundo 2015. Los migrantes y las ciudades: Nuevas colaboraciones para gestionar la movilidad. Ginebra: Organización Internacional para las Migraciones, Available online: http://www.publications.iom.int/system/wmr2015_sp.pdf (accessed on 15 March 2019).

Hinskens, Frans. 1996. Dialect Levelling in Linburg: Structural and Sociolinguistic Aspects. Tübingen: Niemeyer.

Jahan, Selim. 2016. Informe Sobre Desarrollo Humano 2016. Desarrollo humano para todas las personas. Nueva York: Programa de las Naciones Unidas para el Desarrollo, Available online: http://www.undp.org/content/dam/ HDR16OverviewSpanish.pdf (accessed on 1 March 2019).

Johnson, Trev, and Simon Berry. 2014. Beyond the ESOL classroom. In Language issues in Migration and Integration: Perspectives from Teachers and Learners. Edited by Davis Mallows. London: British Council, pp. 79-95.

Kerswill, Paul. 2003. Dialect levelling and geographical diffusion in British English. In Social Dialectology. In Honour of Peter Trudgill. Edited by David Britain and Jenny Cheshire. Amsterdam: John Benjamins, pp. 223-43.

Lonsdale, Deryle, and Yvon Le Bras. 2009. A Frequency Dictionary of French: Core vocabulary for Leaners. London: Routledge. 
Mallows, Davis, ed. 2014. Language Issues in Migration and Integration: Perspectives from Teachers and Learners. London: British Council.

Moreno-Fernández, Francisco. 2009. Integración sociolingüística en contextos de inmigración: marco epistemológico para su estudio en España. Lengua y migración/Language and Migration 1: 121-56.

Moreno-Fernández, Francisco. 2013a. Sociolingüística Cognitiva: Proposiciones, Escolios y Debates. Madrid and Frankfurt: Iberoamericana/Vervuert.

Moreno-Fernández, Francisco. 2013b. Lingüística de las migraciones hispánicas. Lengua y migración/Language and Migration 5: 67-89.

OECD/European Union. 2015. Indicators of Immigrant Integration 2015: Settling In. Paris: OECD Publishing, Available online: http://dx.doi.org/10.1787/9789264234024 (accessed on 1 March 2019).

Piller, Ingrid, ed. 2016. Language and Migration. Critical Concepts in Linguistics. I-IV vols. London and New York: Routledge.

Pons, Diana, Francisco Luis Atienza Isabel Balaguer, and Marisa Garcia-Merita. 2002. Propiedades psicométricas de la escala de satisfacción con la vida en personas de la tercera edad. Revista Iberoamericana de Diagnóstico Evaluación Psicológica 13: 71-82.

Regan, Vera, Chloé Diskin, and Jennifer Martin, eds. 2016. Language, Identity and Migration. Voices from Transnational Speakers and Communities. Bern: Peter Lang.

Sancho-Pascual, María. 2013. La integración sociolingüística de la inmigración hispana en España: lengua, percepción e identidad social. Lengua y migración/Language and Migration 5: 91-110.

Sheppard, Jill. 2015. Australian Attitudes towards National Identity: Citizenship, Immigration and Tradition. Canberra: ANU.

Stokes, Bruce. 2017. Refugees in the Mind of the West. Washington: Pew Research Center for the People \& the Press. Trudgill, Peter. 2002. Sociolinguistic Variation and Change. Edinburgh: Edinburgh University Press.

Villena, Juan Andrés. 2005. How similar are people who speak alike? An interpretive way of using social networds in social dialectology research. In Dialect Change: Convergence and Divergence in European Languages. Edited by Peter Auer, Frans Hinskens and Paul Kerswill. Cambridge: Cambridge University Press, pp. 303-34.

Villena, Juan Andrés, and Matilde Vida. 2017. Between local and standard varieties. Horizontal and vertical convergence and divergence of dialects in Southern Spain. In Language Variation-European Perspectives VI, I. Edited by Isabelle Buchstaller and Beat Siebenhaar. Amsterdam and Philadelphia: John Benjamins, pp. 125-40.

Wheeler, Rebecca. 2019. Attitude Change is Not Enough: Changing teacher practice to disrupt dialect prejudice un the classroom. In Teaching Language Variation in the Classroom. Strategies and Models from Teachers and Linguists. Edited by Michelle D. Devereaux and Chris C. Palmer. New York and London: Routledge, pp. 109-19. 